\title{
Epidemiology of Chronic Obstructive Pulmonary Disease in Brazil: a systematic review and meta-analysis
}

\author{
Epidemiologia da Doença Pulmonar Obstrutiva Crônica no Brasil: \\ uma revisão sistemática e metanálise
}

Marina Malheiro Cruz (https://orcid.org/0000-0003-1917-322X) ${ }^{1}$

Marcos Pereira (https://orcid.org/0000-0003-3766-2502) ${ }^{2}$

${ }^{1}$ Centro de Ciências Biológicas e da Saúde, Universidade Federal do Oeste da Bahia. Barreiras BA Brasil.

${ }^{2}$ Instituto de Saúde Coletiva, Universidade Federal da Bahia. R. Basílio da Gama s/n, Campus Universitário Canela. 40110040 Salvador BA Brasil. pereira.santosm@ yahoo.com

\begin{abstract}
Chronic Obstructive Pulmonary Disease (COPD) is among the leading causes of morbidity and mortality in developing countries; however, few systematic reviews are available in the literature. This review examines the prevalence of COPD in the Brazilian population. For this purpose, a systematic review and meta-analysis was conducted of epidemiological observational studies indexed in the databases PubMed, Cochrane, Ovid, Scopus, ScienceDirect, SciELO, Lilacs, and Google Scholar published up to May 2018. The prevalence was estimated using a random effects model. Of the 1,182 articles identified, 12 were eligible. The prevalence of COPD in Brazil was 17\% (95\%CI: 13-22; $I^{2}=94 \%$ ) and the region with the highest prevalence of COPD was the Center-western region (25\%), followed by the Southeastern region (23\%). The Southern region had the lowest prevalence among the studies (12\%). We found that Brazil has a high occurrence of COPD, higher than the estimates of Latin American and world population Hence, additional studies are necessary to support intervention strategies, as well as formulation of specific public health policies to control and prevent COPD.

Key words Prevalence, COPD, Brazil, Epidemiological surveys, Review
\end{abstract}

Resumo A Doença Pulmonar Obstrutiva Crônica (DPOC) encontra-se entre as principais causas de morbidade e mortalidade em paises em desenvolvimento, contudo, poucos estudos de revisão sistemática estão disponíveis na literatura. Neste sentido, sumarizamos a prevalência de DPOC na população brasileira. Para tanto, foi realizada revisão sistemática e metanálise de estudos epidemiológicos observacionais indexados nas bases de dados PubMed, Cochrane, Ovid, Scopus, ScienceDirect, SciELO, Lilacs, Google Scholar, publicados até maio de 2018. As prevalências foram estimadas utilizando modelo de efeitos aleatórios. Identificaram-se 1.182 e 12 artigos foram elegíveis. A prevalência de DPOC no Brasil foi de 17\% (IC95\%: 13-22; $I^{2}=94 \%$ ) entre adultos maiores de 40 anos e a região de maior prevalência de DPOC é o Centro-Oeste (25\%), seguida pela Região Sudeste (23\%). A Região Sul registrou a menor prevalência entre os estudos (12\%). Conclui-se que o Brasil apresenta elevada ocorrência de DPOC. Desta forma, estudos adicionais são necessários para subsidiar estratégias de intervenção, bem como formulação de políticas públicas de saúde especificas voltadas ao controle e prevenção da DPOC.

Palavras-chave Prevalência, DPOC, Brasil, Inquéritos epidemiológicos, Revisão 


\section{Introduction}

Chronic Obstructive Pulmonary Disease (COPD) is a public health problem worldwide and is among the leading causes of morbidity and mortality, especially in developing countries ${ }^{1,2}$. In 2017 , it was considered the fourth leading cause of death in the world and is estimated to become the third leading cause of death in $2020^{1}$. This severe condition is characterized by the persistence of respiratory symptoms, due to airflow limitation, such as dyspnea, and cough with or without expectoration ${ }^{1,2}$.

Epidemiological studies have shown that COPD is a multifactorial disease and is associated with exposure to environmental pollution, unfavorable socioeconomic conditions, and genetic abnormalities. Among the environmental pollutants, the exposure to smoke from tobacco and burning biomass ${ }^{1,3}$ is associated with COPD.

In 2015, more than 37,000 people died in Brazil due to COPD, according to the Mortality Information System of the Unified Public Health System ${ }^{4}$. Data from a 9-year follow-up study showed that the rate of new cases diagnosed in the city of São Paulo (1.4\% to $4 \%$ ) was similar to the rates found in Europe, Asia, and North America $^{5}$. This demonstrates the need to study this subject to contribute to the development of disease prevention programs.

Systematic reviews of COPD prevalence have been limited to risk factors ${ }^{6-12}$, clinical complications $^{13-15}$, comorbidities ${ }^{16}$, economic impact ${ }^{17-19}$, and treatment of the disease ${ }^{20-22}$. However, the scientific evidence about the occurrence of COPD in populations in developing countries, like Brazil, is limited.

The disease is underdiagnosed and undertreated $^{2}$. In addition, the literature on this disease in Brazil is sparse, which makes it difficult to estimate the impact of COPD on quality of life. This is the first systematic review with meta-analysis to evaluate the prevalence of COPD in Brazil.

\section{Methodology}

This systematic review study was developed according to answer the question: "what is the prevalence of COPD in the Brazilian population?”.

To answer the question, a review protocol was developed and registered at the International Prospective Register of Systematic Reviews (PROSPERO).

\section{Sources of information and search strategies}

Two independent Reviewers (MMC, MP) searched the PubMed, Scopus, Web of Science, Scientific Library Online (SciELO), ScienceDirect, Ovid, Latin American and Caribbean Health Sciences Literature, and Bank of Brazilian Dissertations and Theses (via Capes). To find the publications, the descriptors were: Pulmonary Disease, Chronic Obstructive or COPD, and Brazil (Chart 1). In addition, the literature lists of the relevant studies were examined to identify potentially eligible articles.

Publications were managed in the Mendeley Desktop application (version 1.18@ 2008-2018 Mendeley Ltd.) to remove duplicates and apply inclusion criteria. The search was conducted in April 2018.

\section{Eligibility criteria}

Observational (cross-sectional, cohort, and case-control) studies conducted in Brazil and evaluating the prevalence of COPD in adults were considered eligible.

Evaluated studies must meet the following criteria: FEV1/FVC ratio $<0.70$ obtained through spirometry; mean ages; and city where the study was conducted. Only studies carried out from the year 2000 onwards were considered in meta-analysis. No limits on language or publication status were applied. Studies that evaluated adults with specific health conditions (myocardial ischemia, pulmonary hypertension) were excluded.

\section{Selection of studies and extraction of data}

Following the eligibility criteria, the authors MMC and MP-S independently selected the articles in two steps, evaluating the title and abstract and, later, reading the full text. Disagreements were resolved by consensus.

To extract the data, a spreadsheet was prepared to record information about: the authors; publication year; city; region of the country; age group; sample size; prevalence of COPD; mean ages; standard deviation of age; percentage of prevalence, and equipment used.

For the articles that did not contain all the information, the author was contacted, at least twice, for the necessary clarifications. However, in three studies ${ }^{23-25}$ it was not possible to obtain all because the authors did not respond. 
Chart 1. Database search strategy and results

\begin{tabular}{|c|c|c|}
\hline Database & Search strategy & $\begin{array}{l}\text { Items } \\
\text { found }\end{array}$ \\
\hline PubMed & $\begin{array}{l}\text { ("Pulmonary Disease, Chronic Obstructive”[Mesh] OR ("pulmonary } \\
\text { disease, chronic obstructive”[MeSH Terms] OR ("pulmonary”[All } \\
\text { Fields] AND “disease"[All Fields] AND “chronic"[All Fields] AND } \\
\text { "obstructive"[All Fields]) OR "chronic obstructive pulmonary } \\
\text { disease"[All Fields] OR "copd"[All Fields])) AND "Brazil”[Mesh] }\end{array}$ & 181 \\
\hline Web of science & $\begin{array}{l}\# 1 \mathrm{TS}=\mathrm{COPD}=47.491 \\
\# 2 \mathrm{TS}=\text { Pulmonary Disease, Chronic Obstructive }=44.859 \\
\# 3 \mathrm{TS}=\text { Brazil }=183.324 \\
\# 4 \quad \# 3 \text { AND \#2 AND \#1 }=76\end{array}$ & 76 \\
\hline Scopus & (“Pulmonary Disease, Chronic Obstructive” OR copd AND Brazil) & 203 \\
\hline Science Direct & $\begin{array}{l}\text { "Pulmonary Disease, Chronic Obstructive" OR “COPD" AND "Brazil" } \\
\text { AND “Observational studies" }\end{array}$ & 355 \\
\hline SciELO & doenca pulmonar obstrutiva cronica AND Brasil & 73 \\
\hline Ovid & $\begin{array}{l}\text { \# } 1 \text { Pulmonary Disease, Chronic Obstructive/ }=32366 \\
\text { \# } 2 \text { COPD.mp. }=32826 \\
\text { \# } 3 \text { Brazil.mp. or BRAZIL } /=91298 \\
\text { \# } 41 \text { or } 2=41970 \\
\# 53 \text { and } 4=176\end{array}$ & 176 \\
\hline BVS & chronic obstructive pulmonary disease or COPD and Brazil & 113 \\
\hline CAPES & $\begin{array}{l}\text { Descriptors: } \\
\text { Chronic obstructive pulmonary disease prevalence in Brazill (filters: } \\
\text { health sciences, public health, medicine, pneumology, medicine } \\
\text { (pneumology);): } 494 \text { results }\end{array}$ & 494 \\
\hline Pulmonology and COPD & $4(2010,2012,2014,2017)$ & 4 \\
\hline
\end{tabular}

\section{Evaluation of the methodological quality of included studies}

To assess the risk of bias, a tool developed by Hoy et al..$^{26}$ was used, which adopts the criteria 1) probabilistic or census sampling; 2 ) adequate sampling source (official census, school census, among others); 3) sample size previously calculated; 4) adequate post-bronchodilator spirometry FEV1/ FVC; 5$)$ adequate response rate $(>70.0 \%)$ and description of refusals; 6 ) presentation of confidence intervals and analysis of subgroups of interest; and 7) study subjects well described and similar to the research question. Each item received a score of 1 (yes) or 0 (no). Scoring on all items can generate an overall quality score ranging from 0 to 10 . According to the scores, risk of bias is classified as low (>8 points), moderate $(6-8)$, or high $(\leq 5)$.

\section{Data analysis}

The primary outcome was the prevalence of COPD, with a $95 \%$ confidence interval $(95 \% \mathrm{CI})$.
The prevalence of the disease was estimated for the total population and defined subgroups of interest: women; sample size, region of the country, and risk of bias.

The DerSimonian and Laird method was used to estimate the variability parameter between the studies. The heterogeneity was assessed by the Cochran test and Q test, and its magnitude was ascertained by I-square $\left(\mathrm{I}^{2}\right)^{27}$. Data from the studies included in the meta-analysis were transformed through the logit function to satisfy the normality assumption of the meta-analytic model of random effects. The confidence intervals for the results of the individual studies were calculated using the Coppler-Pearson method.

Meta-regressions were used to identify the causes of heterogeneity using the Knapp and Hartung test to analyze the following variables: quality score, sample size, proportion of females and males, publication year, and region of the study. The publication bias was not evaluated since it is not adequate in the meta-analyzes of prevalence. 
In all analyzes the $\mathrm{p}$ value $<0.05$ was considered statistically significant. Statistical analyzes were performed using the STATA 12 program (Stata Corp., College Station, TX, USA).

\section{Results}

\section{Characteristics of the analyzed studies}

The search strategies are presented in Figure 1. We identified 1,182 articles in the eight databases. After the removing the duplicate records, 47 remained for title and abstract analyses; 20 were selected for qualitative synthesis , $12,22-24,28-42$ and 12 were included in the meta-analysis, ${ }^{2,12,23-25,29,34-39}$. The reasons for excluding the articles were the absence of the association measure $(n=2)$, absence of COPD prevalence in Brazil $(n=25)$.

The main characteristics of the selected studies are presented in Table 1. Most of the articles selected $(67 \%)$ were published after 2010, with samples varying from 67 to 1,059 participants; $50 \%$ of the studies have a sample number above 300 . The total number of participants was 4,812 . For geographic regions of the studies, there was a higher concentration in the southern region (42\%) of Brazil (Table 1).

A predominance of cross-sectional design ( $\mathrm{n}$ $=12$ ) was observed, as well as a predominance of articles with methodological quality classified as strong $(n=7 ; 58 \%)$. Articles from cross-sectional studies obtained a higher frequency of strong scores in risk of bias assessment (Chart 2).

\section{Meta-analysis results}

The results of the meta-analysis of COPD prevalence are shown in Table 1 . The prevalence of COPD in Brazil was 17\% (95\%CI $=13-22$ ) (Figure 2). There was signifcant heterogeneity across the included studies $\left(\mathrm{I}^{2}=94 \%\right)$.

The region of the country with the highest prevalence was the Central-Western (25\%, $95 \% \mathrm{CI}=15-35 ; \mathrm{I}^{2}=0 \%$ ), followed by the Southeastern region $\left(23 \%, 95 \% \mathrm{CI}=16-30 ; \mathrm{I}^{2}=0 \%\right)$. The Southern region had the lowest prevalence among the studies $\left(12 \%, 95 \% \mathrm{CI}=16-30 ; \mathrm{I}^{2}=\right.$ 95.3\%).

The prevalence of COPD in men was higher $\left(16 \%, 95 \% \mathrm{CI}=6-26 ; \mathrm{I}^{2}=96 \%\right)$ than women $\left(13 \%, 95 \% \mathrm{CI}=5-20 ; \mathrm{I}^{2}=96 \%\right)$. The prevalence was similar in the studies conducted between 2000 and 2004 (20\%, 95\%CI =14-26; $\left.\mathrm{I}^{2}=0 \%\right)$ than in the subsequent studies (Table 2).
The articles classified as moderate risk of bias corresponded to $42 \%(\mathrm{n}=5)$ of the total, in which prevalence was $24 \%\left(95 \% \mathrm{CI}=13-34 ; \mathrm{I}^{2}=\right.$ $94 \%)$, while studies with low risk registered less prevalence of COPD $\left(16 \%, 95 \% \mathrm{CI}=11-21 ; \mathrm{I}^{2}=\right.$ 95\%) (Table 2).

The meta-regression for the variables: risk of bias, sample size, proportion of female and male subjects, publication year, and region of the study analyzed did not explain the possible causes of the heterogeneity found in the analysis of the studies $(\mathrm{p}>0.05)$.

\section{Discussion}

This study was the first meta-analysis to estimate the prevalence of COPD in Brazil, based on observational studies that used as a diagnostic criterion from spirometry for COPD.

The occurrence of COPD in this study was $17 \%(95 \% \mathrm{CI}=13-22)$, which is higher than the estimated $11.4 \%$ for the world population $(95 \% \mathrm{CI}=8.4-15.0)^{43}$. In 2010, the World Health Organization estimated that the region with the highest prevalence of COPD was in the Americas $(15.2 \%, 95 \% \mathrm{CI}=14.9-15.5)$ and the lowest in Southeast Asia (9.7\%). Thus, the prevalence in Brazil exceeds the average of the world regions ${ }^{44,45}$.

Most studies report a prevalence of COPD ranging from 8 to $10 \%$ among adults ${ }^{33}$, with cigarette smoking the most important risk factor. However, occupational and environmental exposures are important for disease progression and onset, especially in developing countries. The latest statistics from COPD identify a gradual decline in some parts of the world in relation to morbidity and mortality. However, in Brazil, we found that the prevalence among adults and the elderly is significant (19\%), which implies large economic and social expenditures, such as hospitalizations ${ }^{46-48}$. In the US, each exacerbation costs $\$ 88$ to $\$ 7,757^{19}$. The estimated mortality in hospitalizations for COPD in the Caribbean ranged from $6.7 \%$ to $29.5 \%{ }^{44}$. Therefore, COPD is a severe condition with substantial impact on the Brazilian public health system. In view of this, measures to prevent environmental exposures, such as biomass burning and programs to encourage smoking cessation, are essential to combat the current situation.

A possible explanation for the high prevalence of COPD in the Brazilian population may be related to the extensive use of wood stoves for domestic needs, because the use of solid fu- 


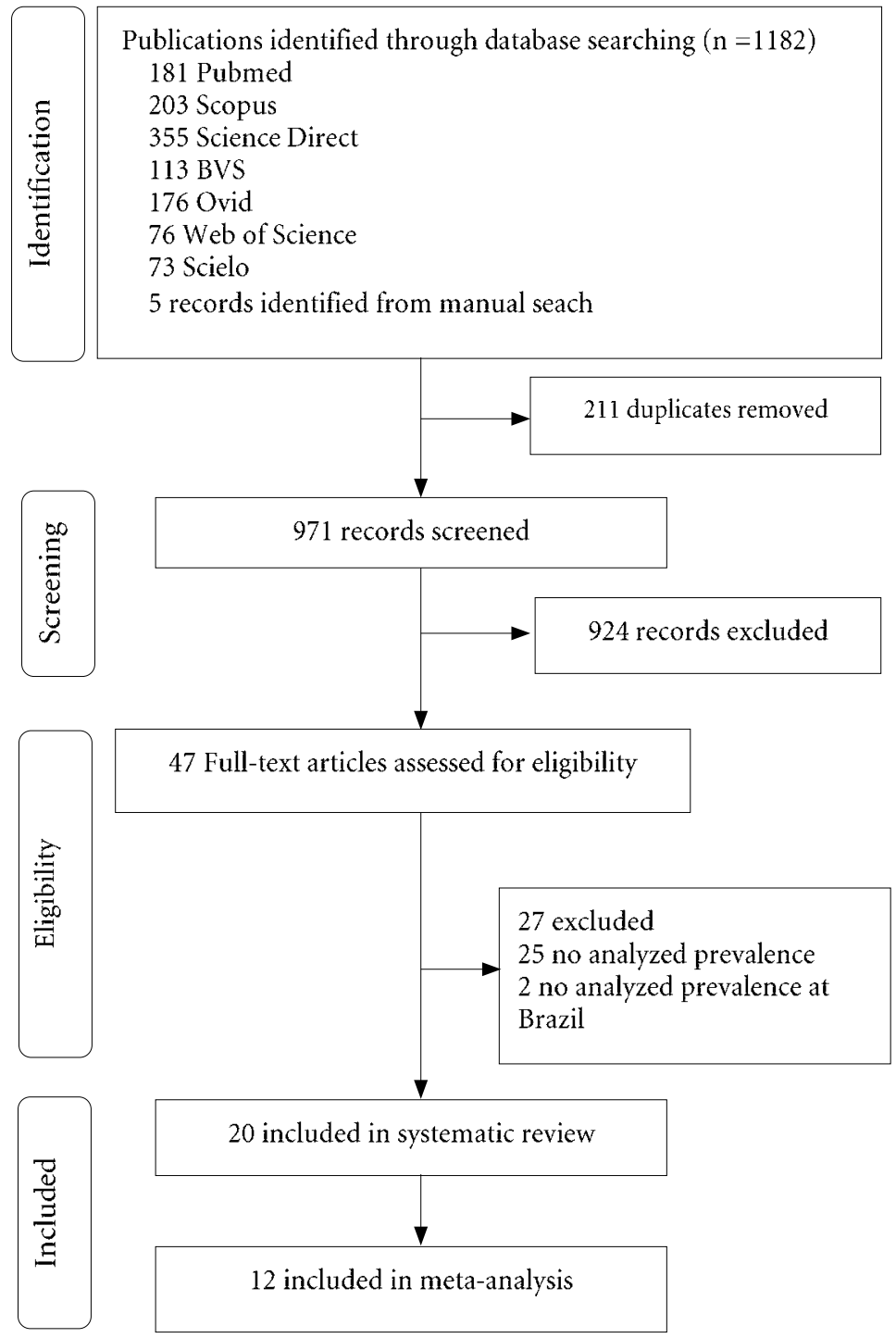

Figure 1. Study selection flowchart.

els in rural households in developing countries is high ${ }^{49}$. The etiology of COPD is multifactori$\mathrm{al}$, with smoking and exposure to environmental pollution the most important etiological causes ${ }^{1}$.

A study published in 2014 analyzed COPD mortality in Brazil from 1980 to 2014. It found an increase from 1998-2004, followed by a decrease, with the highest rates concentrated in the Southeastern and Southern regions $s^{48}$. Another study that also evaluated COPD mortality between 1996-2008 showed higher rates among men $(2.7 \%, 95 \% \mathrm{CI}=3.6$ to -1.8$)$ than in women $(-2.0 \%, 95 \% \mathrm{CI}=2.9 \text { to }-1.0)^{47}$. These studies ver- ified that this disease has irregular affections rates in the population, which entail substantial costs to the Health System.

A study carried out in São Paulo showed that, among the 206,764 hospitalizations due to respiratory diseases between 1995 and 2000, COPD was the third main cause (5.8\% of the total), with the higher rate in men (6.09\% versus 5.53\%) and the mean age was 57.7 years ${ }^{48}$.

The Central-Western region had the highest prevalence of COPD. Explanation for this record needs to be established, as few studies associate possible environmental exposures or population 
Table 1. Description of the studies included in the qualitative synthesis and meta-analysis of Chronic Obstructive Pulmonary Disease in Brazil.

\begin{tabular}{|c|c|c|c|c|c|c|c|}
\hline Authors, Year & Location & Type & Sample & Year of collection & Mean age & Prevalence of COPD & Meta-analysis \\
\hline Queiroz et al, $2012^{25}$ & Aparecida de Goiânia - GO & Cross-section & 200 & 2011 & 66 & 31 & Yes \\
\hline Moreira et al., $2013^{39}$ & Goiânia - GO & Cross-section & 160 & - & 70 & 26 & Yes \\
\hline Carvalho et al., $2012^{24}$ & São Paulo - SP & Cross-section & 918 & - & 55 & 16 & Yes \\
\hline Menezes et al., $2005^{2}$ & São Paulo - SP & Cross-section & 963 & 2003-2004 & 55 & 16 & Yes \\
\hline Rabahi et al., $2015^{23}$ & Goiânia - GO & Cross-section & 316 & 2011-2012 & 68 & 16 & Yes \\
\hline Landis et al., $2014^{40}$ & Brazil & Cross-section & 300 & 2012-2013 & $40-49$ & 12 & Yes \\
\hline Menezes et al., $2004^{12}$ & Pelotas -RS & Cross-section & 191 & 2001 & $40-49$ & 15 & Yes \\
\hline Souza et al., $2010^{29}$ & $\begin{array}{l}\text { Lindolfo Collor, Presidente Lucena and Ivoti } \\
\text { - RS }\end{array}$ & Cross-section & 67 & 2007 & 46 & 6 & Yes \\
\hline Cavalli, $2015^{41}$ & Florianópolis - SC & Cross-section & 1059 & $2010-2013$ & 65 & 9 & Yes \\
\hline Pisoni, $2007^{36}$ & Novo Hamburgo - RS & Cross-section & 186 & 2005-2006 & $40-49$ & 4 & Yes \\
\hline Kaisermann, $2006^{37}$ & Rio de Janeiro - RJ & Cross-section & 117 & $2005-2006$ & $>40$ & 46 & Yes \\
\hline Santos et al., $2014^{38}$ & Uberaba - MG & Cross-section & 335 & 2012 & 71 & 21 & Yes \\
\hline Menezes et al., $2008^{28,34}$ & São Paulo - SP & Cross-section & 963 & 2003 & $>40$ & 14 & No \\
\hline Carandina, $1986^{31}$ & Botucatu - SP & Cross-section & 7075 & 1983-1984 & $>15$ & 0 & No \\
\hline Sousa et al., $2011^{42}$ & São Paulo - SP & Cross-section & 1441 & 2008-2009 & $>40$ & 4 & No \\
\hline Carvalho et al., $1986^{32}$ & Salvador - BA & Case-control & $\begin{array}{l}1562 \exp \\
1351 \text { con }\end{array}$ & 1984 & $>50$ & $\mathrm{RP}=3$ & No \\
\hline Deolinda et al., $2010^{30}$ & Criciúma - SC & Cross-section & 6169 & 2009 & - & 4 & No \\
\hline Nascimento et al., $2007^{33}$ & São Paulo - SP & Cross-section & 918 & 2003 & 60 & 16 & No \\
\hline Talamo et al., $2007^{35}$ & São Paulo - SP & Cross-section & 961 & 2003 & 64 & 14 & No \\
\hline
\end{tabular}


Table 2. Prevalence of Chronic Obstructive Pulmonary Disease in Brazil, by subgroup.

\begin{tabular}{|c|c|c|c|c|c|}
\hline Subgroup & $\begin{array}{c}\text { Number of } \\
\text { studies }\end{array}$ & $\begin{array}{c}\text { Number of } \\
\text { participants }\end{array}$ & $\begin{array}{c}\text { Prevalence } \\
(\%)\end{array}$ & 95\%CI & $\mathbf{I}^{2}(\%)$ \\
\hline \multicolumn{6}{|l|}{ Collection year } \\
\hline $2000-2004$ & 3 & 2072 & 20 & $14-26$ & 0 \\
\hline $2005-2007$ & 3 & 370 & 18 & $1-38$ & 0 \\
\hline $2008-2015$ & 6 & 2379 & 19 & $12-25$ & 94.3 \\
\hline \multicolumn{6}{|l|}{ Sex } \\
\hline Male & 8 & 1118 & 16 & $6-26$ & 96.0 \\
\hline Female & 6 & 1518 & 13 & $5-20$ & 96.2 \\
\hline \multicolumn{6}{|l|}{ Risk of bias } \\
\hline Moderate & 5 & 1035 & 24 & $13-34$ & 94.5 \\
\hline Low & 7 & 3777 & 16 & $11-21$ & 95.5 \\
\hline \multicolumn{6}{|l|}{ Region of Brazil } \\
\hline Central-West & 3 & 676 & 25 & $15-35$ & 0 \\
\hline Southeast & 4 & 2333 & 23 & $16-30$ & 0 \\
\hline South & 4 & 1503 & 12 & $04-20$ & 95.35 \\
\hline Brazil & 1 & 300 & - & - & - \\
\hline
\end{tabular}

Chart 2. Risk bias assessment using Roy for the studies included in the meta analysis.

\begin{tabular}{|c|c|}
\hline Authors, Year & Hoy score \\
\hline Queiroz et al., $2012^{25}$ & 8 \\
\hline Moreira et al., $2013^{39}$ & 9 \\
\hline Carvalho et al., $2012^{24}$ & 9 \\
\hline Menezes et al., $2005^{2}$ & 9 \\
\hline Rabahi et al., $2015^{23}$ & 6 \\
\hline Landis et al., $2014^{40}$ & 9 \\
\hline Menezes et al., $2004^{12}$ & 9 \\
\hline Souza et al., $2010^{29}$ & 7 \\
\hline Cavalli, $2015^{41}$ & 9 \\
\hline Pisoni, $2007^{36}$ & 9 \\
\hline Kaisermann, $2006^{37}$ & 6 \\
\hline Santos et al., $2014^{38}$ & 8 \\
\hline
\end{tabular}

factors to the occurrence of COPD. However, the prevalence found in the Central-western and Southeast regions were similar. A possible factor associated with COPD may be exposure to biomass burning. Especially in the Southern and Southeastern regions of Brazil, the production of firewood and charcoal increased between 2016 and $2017^{49}$.

The Northern and Northeastern regions were not represented in this study because there was no study published the fit the scope of this review. Thus, studies on the prevalence of COPD in these states needs to be carried out, because this region has major producers of risk factors for the disease.

In this meta-analysis, the prevalence of COPD in men was $16 \%(95 \% \mathrm{CI}=6-26)$, which is 1.02 times higher than in women $(13 \%, 95 \% \mathrm{CI}=$ 5-20). In the United States, the prevalence in women $(5.4 \%)$ was higher than in men $(2.8 \%)$. In other countries, such as China and Finland, COPD in both men and women is lower than the results of the present study ${ }^{10,50}$. Our result is similar to that found in the Americas, where the prevalence of the disease among men was $17.6 \%$ (95\%CI = 14.6-20.6) and women 11.8 (95\%CI = 9.7-13.9) $)^{34}$, as well as in the Caribbean and Latin America in $2010^{36}$, in which the prevalence in men was 1.76 times higher than women $(10.4 \%$, $95 \% \mathrm{CI}=7.6-13.6$ vs. $18.2 \%, 95 \% \mathrm{CI}=14.1-22.6)$. The prevalence of COPD among men is estimated to be $14.3 \%(95 \% \mathrm{CI}=13.3-15.3)$ and women, $7.6 \%(95 \% \mathrm{CI}=7.0-8.2)$, which is lower than our results.

The results of this meta-analysis evidenced that COPD predominantly affects people over 55 years old. The lowest prevalence was recorded in the population of Novo Hamburgo, a city in the Southern Brazil, in contrast to Rio de Janeiro, in Southeastern Brazil, where the highest prevalence of the disease was described ${ }^{36}$. 


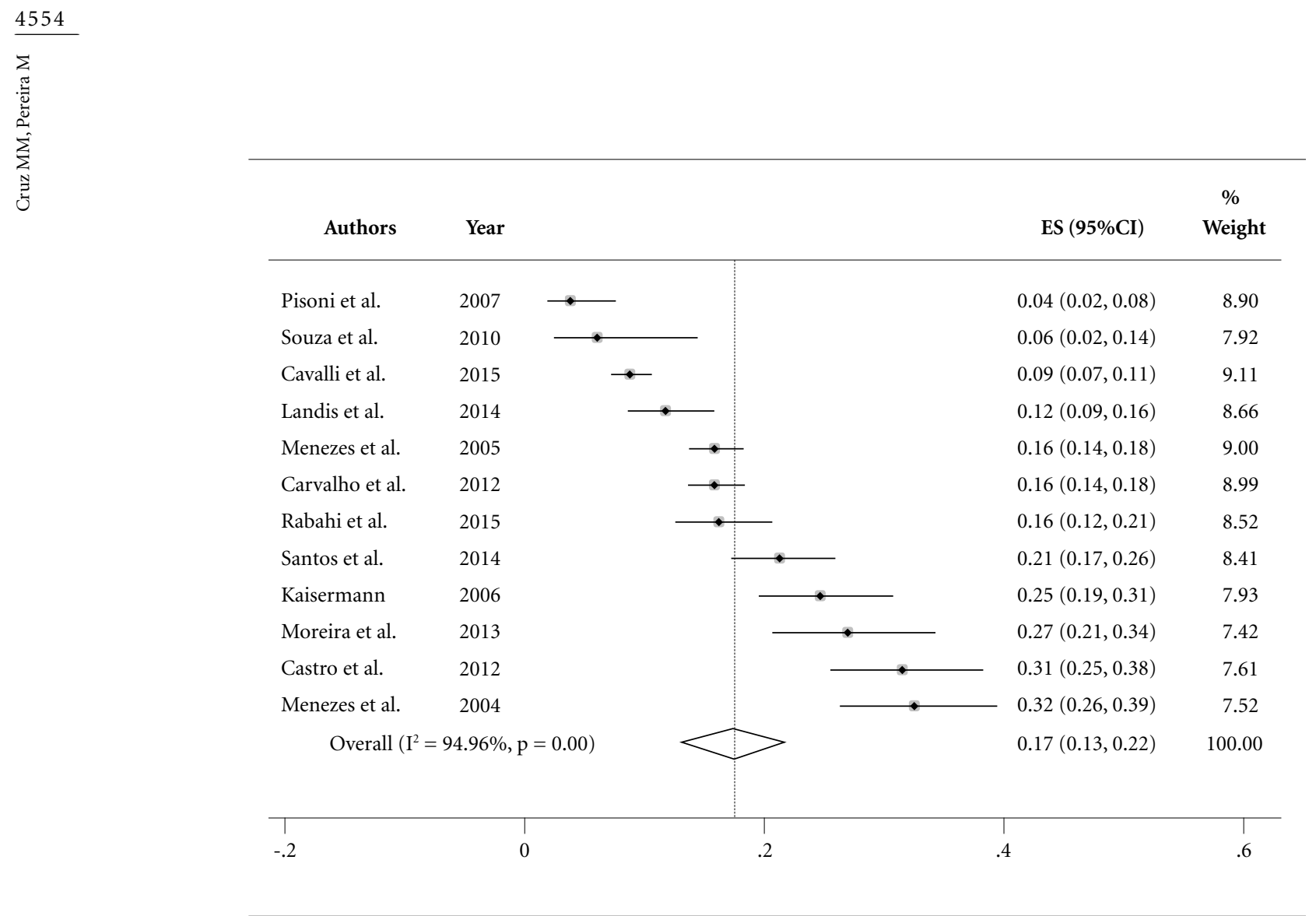

Figure 2. Forest plot of the prevalence of Chronic Obstructive Pulmonary Disease in Brazil in 12 epidemiological studies.

The largest sample size in the studies occurred mostly after 2010 . On the other hand, the highest prevalence recorded were concentrated in the period between 2004 and 2007, because they had a smaller sample size, as well as selection bias or inadequate sampling technique.

The great volubility in the quality of the studies attributed to the high probability of non-response bias, as the type of sampling was often not random. Therefore, many of the selected studies were considered to have moderate risk of bias. Thus, the appropriate sampling process as well as the methodological quality of the study should be considered in future studies to minimize the risk of bias.

Cross-sectional studies were predominant, as was the diagnostic method through spirometry, which was applied individually in most of the studies. In addition, all studies applied consolidated protocols in the literature to evaluate COPD. Thus, the spirometric result, in which the ratio of forced expiratory volume (FEV1) divided by forced vital capacity (CFV) is less than 0.7 , according to the latest guideline of the Global Initiative for Chronic Obstructive Lung Disease ${ }^{1}$, which was the primary diagnostic criterion for COPD applied in the selection of studies. However, one study used medical diagnostic criteria and adherence to the recommended treatment for the disease ${ }^{42}$.

This meta-analysis has limitations. Possibly because there are few studies conducted in Brazil, and none in the Northern and Northeastern Regions. In addition, due to different age categories, it was not possible to estimate the prevalence of COPD by age group in Brazil. We also had difficulties in obtaining data from selected studies, due to the lack of response from authors of the studies included in the meta-analysis. Nevertheless, methodological rigor and well-established criteria make this study consistent.

Finally, the results found in this study indicate that COPD is a frequently occurring problem in Brazil, higher than the estimates of Latin American and world population. Nevertheless, new studies covering not only the criteria already 
mentioned, but also the Northern and Northeastern regions are necessary to extensively investigate the impact of COPD in Brazil and help to develop interventions.

\section{Collaborations}

M Pereira and MM Cruz developed the study concept, draft of the manuscript and approved the final manuscript. M Pereira supervised the study process.

\section{References}

1. Global Initiative for Chronic Obstructive Lung Disease (GOLD Committee). Global Strategy for The Diagnosis, Management, And Prevention of Chronic Obstructive Lung Disease Report. Fontana: GOLD; 2017.

2. Menezes AMB, Perez-Padilla R, Jardim JRB, Muino A, Lopez MV, Valdivia G, PLATINO Team. Chronic obstructive pulmonary disease in five Latin American cities (the PLATINO study): a prevalence study. Lancet 2005; 366(9500):1875-1881.

3. Gouveia N, Corrallo FP, Leon ACP, Junger W, Freitas CU. Air pollution and hospitalizations in the largest Brazilian metropolis. Rev Saude Publica 2017; 51:117.

4. TabNet Win32 3.0. Morbidade Hospitalar do SUS - por local de internação - Estados [Internet]. [cited 2018 Jun 28]. Available from: http://tabnet.datasus.gov.br/ cgi/deftohtm.exe?sih/cnv/nipr.def

5. Lopes AJ, Melo PL. Brazilian studies on pulmonary function in COPD patients: what are the gaps? Int J Chron Obstruct Pulmon Dis 2016; 11:1553-1567.

6. DeVries R, Kriebel D, Sama S. Outdoor Air Pollution and COPD-Related Emergency Department Visits, Hospital Admissions, and Mortality: A Meta-Analysis. COPD 2017; 14(1):113-121.

7. Ryu JY, Sunwoo YE, Lee SY, Lee CK, Kim JH, Lee JT, Kim DH. Chronic Obstructive Pulmonary Disease (COPD) and Vapors, Gases, Dusts, or Fumes (VGDF): A Meta-analysis. COPD 2015; 12(4):374-380.

8. Nielsen AO, Jensen CS, Arredouani MS, Dahl R, Dahl M. Variants of the ADRB2 Gene in COPD: Systematic Review and Meta-Analyses of Disease Risk and Treatment Response. COPD 2017; 14(4):451-460.

9. Schauer GL, Wheaton AG, Malarcher AM, Croft JB. Smoking Prevalence and Cessation Characteristics among U.S. Adults with and without COPD: Findings from the 2011 Behavioral Risk Factor Surveillance System. COPD 2014; 11(6):697-704.

10. Kotaniemi J-T, Sovijärvi A, Lundbäck B. Chronic Obstructive Pulmonary Disease in Finland: Prevalence and Risk Factors. COPD 2005; 2(3):331-339.

11. Llordés M, Jaén A, Almagro P, Heredia JL, Morera J, Soriano JB, Miravitlles M. Prevalence, Risk Factors and Diagnostic Accuracy of COPD Among Smokers in Primary Care. COPD 2015; 12(4):404-412. 
12. Menezes A, Macedo SC, Gigante DP, da Costa JD, Olinto MT, Fiss E, Chatkin M, Hallal PC, Victora CG. Prevalence and risk factors for chronic obstructive pulmonary disease according to symptoms and spirometry. COPD 2004; 1(2):173-179.

13. Rodríguez-Rodríguez P, Jiménez-García R, Hernández-Barrera V, Carrasco-Garrido P, Puente-Maestu L, Miguel-Díez J. Prevalence of Physical Disability in Patients with Chronic Obstructive Pulmonary Disease and Associated Risk Factors. COPD 2013; 10(5):611617.

14. Buist AS, Vollmer WM, Sullivan SD, Weiss KB, Lee TA, Menezes AMB, Crapo RO, Jensen RL, Burney PG. The Burden of Obstructive Lung Disease Initiative (BOLD): Rationale and Design. COPD 2005; 2(2):277-283.

15. Battaglia S, Basile M, Scichilone N, Bellia V. Prevalence of Co-morbidities and Severity of COPD. COPD 2015; 12(4):390-394.

16. Cebron Lipovec N, Beijers RJHCG, van den Borst B, Doehner W, Lainscak M, Schols AMWJ. The Prevalence of Metabolic Syndrome in Chronic Obstructive Pulmonary Disease: A Systematic Review. COPD 2016; 13(3):399-406.

17. Foster TS, Miller JD, Marton JP, Caloyeras JP, Russell MW, Menzin J. Assessment of the Economic Burden of COPD in the U.S.: A Review and Synthesis of the Literature. COPD 2006; 3(4):211-218.

18. Gershon AS, Dolmage TE, Stephenson A, Jackson B. Chronic Obstructive Pulmonary Disease and SocioEconomic Status: a Systematic Review. COPD 2012; 9(3):216-226.

19. Toy EL, Gallagher KF, Stanley EL, Swensen AR, Duh MS. The Economic Impact of Exacerbations of Chronic Obstructive Pulmonary Disease and Exacerbation Definition: A Review. COPD 2010; 7(3):214228.

20. Maltais F, Dennis N, Chan CKN. Rationale for Earlier Treatment in COPD: A Systematic Review of Published Literature in Mild-to-Moderate COPD. COPD 2013; 10(1):79-103.

21. Festic E, Bansal V, Gupta E, Scanlon PD. Association of Inhaled Corticosteroids with Incident Pneumonia and Mortality in COPD Patients; Systematic Review and Meta-Analysis. COPD 2016; 13(3):312-326.

22. Zheng P-F, Shu L, Si C-J, Zhang X-Y, Yu X-L, Gao W. Dietary Patterns and Chronic Obstructive Pulmonary Disease: A Meta-analysis. COPD 2016 ;13(4):515-522.

23. Rabahi M, Pereira SA, Rodrigues Junior JL, Rezende AP, Costa AC, Corrêa KS, Conde MB. Prevalence of chronic obstructive pulmonary disease among patients with systemic arterial hypertension without respiratory symptoms. Int J Chron Obstruct Pulmon Dis 2015; 10:1525-1529.

24. Carvalho AK, Menezes AMB, Camelier A, Rosa FW, Nascimento OA, Perez-Padilla R, Jardim JR. Prevalence of self-reported chronic diseases in individuals over the age of 40 in São Paulo, Brazil: The PLATINO study. Cad Saude Publica 2012; 28(5):905-912.

25. Queiroz MCC, Carmo Moreira MA, Rabahi MF, Queiroz MCCAM, Moreira MAC, Rabahi MF. Underdiagnosis of COPD at primary health care clinics in the city of Aparecida de Goiania, Brazil. J Bras Pneumol 2012; 38(6):692-699.
26. Hoy D, Brooks P, Woolf A, Blyth F, March L, Bain C, Baker P, Smith E, Buchbinder R. Assessing risk of bias in prevalence studies: Modification of an existing tool and evidence of interrater agreement. J Clin Epidemiol 2012; 65(9):934-939.

27. Dersimonian R, Laird N. Meta-Analysis in Clinical Trials. Stat Med 1986; 188:177-188.

28. Menezes AMB, Perez-Padilla R, Hallal PC, Jardim JR, Muino A, Lopez MV, Valdivia G, Pertuza J, Oca MM, Tálamo C, PLATINO Team. Worldwide burden of COPD in high- and low-income countries. Part II. Burden of chronic obstructive lung disease in Latin America: the PLATINO study. Int J Tuberc Lung Dis 2008; 12(7):709-712.

29. Souza RM, Andrade FM, Moura ABD, Teixeira PJZ. Respiratory symptoms in charcoal production workers in the cities of Lindolfo Collor, Ivoti and Presidente Lucena, Brazil. J Bras Pneumol 2010; 36(2):210-217.

30. Deolinda GZ, Yamane A, Souza FJFB, Filho AJS. Prevalência de pacientes internados com diagnóstico clínico e espirométrico de doença pulmonar obstrutiva crônica num hospital da região sul de Santa Catarina. J Bras Pneumol 2010; 36(Supl. 2R):92.

31. Carandina L. Prevalence of symptoms suggesting unspecific chronic respiratory diseases in the urban population of Botucatu, São Paulo [thesis]. São Paulo: Universidade de São Paulo; 1986.

32. Carvalho FM, Silvany Neto AM, Lima MEC. Diseases of the repiratory system in a population residing nearly a chocolate factory in Salvador, Bahia. Rev Baiana Saúde Pública 1986; 13(1/3):33-46.

33. Nascimento OA, Camelier A, Rosa FW, Menezes AM, Pérez-Padilla R, Jardim JR, Latin American Project for the Investigation of Obstructive Lung Disease (PLATINO) Group. Chronic obstructive pulmonary disease is underdiagnosed and undertreated in São Paulo (Brazil): results of the PLATINO study. Braz J Med Biol Res 2007; 40(7):887-895

34. Menezes AM, Muiño A, López-Varela MV, Valdivia G, Lisboa C, Jardim JR, Montes de Oca M, Tálamo C, Wehrmeister FC, Perez-Padilla R; Equipo del estudio Platino. A population-based cohort study on chronic obstructive pulmonary disease in Latin America: methods and preliminary results. The PLATINO Study Phase II. Arch Bronconeumol 2014; 50(1):10-17.

35. Tálamo C, Oca MM, Halbert R, Perez-Padilla R, Jar$\operatorname{dim}$ JRB, Muiño A, Lopez MV, Valdivia G, Pertuzé J, Moreno D, Menezes AMB, PLATINO team. Diagnostic labeling of COPD in five Latin American cities. Chest 2007; 131(1):60-67.

36. Pisoni TM. Prevalência da doença pulmonar obstrutiva crônica (DPOC) e fatores de risco ambientais nos bairros mais populosos de Novo Hamburgo [dissertation]. Novo Hamburgo: Centro Universitário Feevale; 2007.

37. Kaisermann M. XXXIII Congresso Brasileiro de Pneumologia e Tisiologia 2006. 2006; 238(Supl. 5):104.

38. Santos SR, Lizzi ES, Vianna EO. Characteristics of undiagnosed COPD in a senior community center. Int $J$ Chron Obstruct Pulmon Dis 2014; 9:1155-1161.

39. Moreira MAC, Barbosa MA, Jardim JR, Queiroz MCC, Inácio LU. Chronic obstructive pulmonary disease in women exposed to wood stove smoke. Rev Assoc Med 2013; 59(6):607-613. 
40. Landis SH, Muellerova H, Mannino DM, Menezes AM, Han MK, van der Molen T, Ichinose M, Aisanov Z, Oh YM, Davis KJ. Continuing to confront COPD international patient survey: Methods, COPD prevalence, and disease burden in 2012-2013. Int J Chron Obstruct Pulmon Dis 2014; 9:597-607.

41. Cavalli F. Of Chronic Obstructive Pulmonary Disease Prevalence of COPD In Florianopolis and associated factors: population based study [dissertation]. Florianópolis: UFSC; 2015.

42. Sousa CA, César CLG, Barros MBA, Carandina L, Goldbaum M, Pereira JCR. Doença pulmonar obstrutiva crônica e fatores associados em São Paulo, SP, 2008-2009. Rev Saude Publica 2011; 45(5):887-896.

43. Adeloye D, Chua S, Lee C, Basquill C, Papana A, Theodoratou E, Nair H, Gasevic D, Sridhar D, Campbell H, Chan KY, Sheikh A, Rudan I, Global Health Epidemiology Reference Group (GHERG). Global and regional estimates of COPD prevalence: Systematic review and meta-analysis. J Glob Health 2015; 5(2):20415.

44. Ciapponi A, Alison L, Agustina M, Demián G, Silvana $\mathrm{C}$, Edgardo $\mathrm{S}$. The Epidemiology and Burden of COPD in Latin America and the Caribbean: Systematic Review and Meta-Analysis. COPD 2014; 11(3):339-350

45. World Health Organization (WHO). World Health Statistics 2010. Geneva: WHO; 2010.

46. Graudenz GS, Gazotto GP. Mortality trends due to chronic obstructive pulmonary disease in Brazil. Rev Assoc Med Bras 2014; 60(3):255-261.

47. Benseñor IM, Fernandes TG, Lotufo PA. Chronic obstructive pulmonary disease in Brazil: mortality and hospitalization trends and rates, 1996-2008. Int J Tuberc Lung Dis 2011; 15(3):399-404.

48. Toyoshima MTK, Ito GM, Gouveia N. Trends in morbidity for respiratory diseases among hospitalized patients in the city of São Paulo. Rev Assoc Med Bras 2005; 51(4):209-213.

49. Simioni FJ, Moreira JMMAP, Fachinello AL, Buschinelli CCA, Matsuura MISF. Evolution and concentration of the production of firewood and charcoal from forestry in Brazil. Ci Fl 2017; 27(2):731-742.

50. Zhong N, Wang C, Yao W, Chen P, Kang J, Huang S, Chen B, Wang C, Ni D, Zhou Y, Liu S, Wang X, Wang D, Lu J, Zheng J, Ran P. Prevalence of chronic obstructive pulmonary disease in China: A large, population-based survey. Am J Respir Crit Care Med 2007; 176(8):753-760.

Article submitted 25/10/2018

Approved 25/02/2019

Final version submitted 27/02/2019 
